\title{
Research on the Reform of the Review Method of College Professional Titles Based on Point System
}

\author{
Weihuang Dai*, Xiaofang Chen \\ South China Business College, Guangdong University of Foreign Studies, Guangzhou, China \\ Email:*975690566@qq.com
}

How to cite this paper: Dai, W.H. and Chen, X.F. (2018) Research on the Reform of the Review Method of College Professional Titles Based on Point System. Journal of Service Science and Management, 11, 455-465.

https://doi.org/10.4236/jssm.2018.114031

Received: April 1, 2018

Accepted: August 26, 2018

Published: August 29, 2018

Copyright (c) 2018 by authors and Scientific Research Publishing Inc. This work is licensed under the Creative Commons Attribution International License (CC BY 4.0).

http://creativecommons.org/licenses/by/4.0/

\begin{abstract}
Taking the confidentiality principle of professional title as the entry point, based on the existing problems of college titles, such as simple feedback mechanism, being lack of pertinence, unfairness, etc., this paper proposes a new title review method based on the point system to change the traditional system review voting method. At the same time, the review index method is introduced, and the specific operation of the case is described in detail by Analytic Hierarchy Process (AHP) and Precedence Chart (PC). It is hoped that through the reform of the review method, the openness and fairness of professional title review process will be further improved, and the incentive effect of college titles should be brought into play to promote the long-term development of colleges and teachers.
\end{abstract}

\section{Keywords}

Point System, College Title, Review Index, Incentive Effect

\section{Introduction}

On June 30th, 2017, Department of Education, Organizing Committee Office, Development and Reform Commission, Department of Finance and Department of Human Resources and Social Security of Guangdong Province jointly issued Implementation Opinions on Deepening the Reform of Simple Administration and Optimization Service of Higher Education in Guangdong Province ("IODRSAOSHEGD" for short) and related guidance document. Since the introduction of the documents, the reform of the title of Guangdong Province has been carried out in full swing. In particular, colleges and universities that had no prior title review rights before have to undertake review rights and achieve 
smooth transitions for the titles for teaching, research, experiments, books and information, which is a question worth exploring.

According to Article 19 of Guangdong Human Resource and Employment (1996) Document No. 3 and Article 20 of Guangdong Human Resource and Employment (1998) Document No. 17, the committee members of the jury, the members of the judging panel and the staff of the daily work department of the jury shall strictly abide by six provisions, such as don't disclose the discussion and voting situation of the jury and the judging panel; don't accept the inquiry about the assessment situation; don't have the obligation to report the assessment to the leader of the unit. In the past review activities, from the perspective of confidentiality, those applicants who failed to get titles can only know they were "unsuccessful", but cannot know the reasons for the failures or the unsuccessful aspects or the striving direction. Because the previous professional review committees generally use voting methods to review each applicant, and the jury members can vote in a simple way, such as "yes" or "no". Therefore, a lot of factors, such as "personality", "difference", "general", "argument" and "internal negotiation" are mixed, and the effective feedback of the review information cannot be achieved [1] [2].

According to the spirit of the "IODRSAOSHEGD" document, this paper starts from the principle of the point system, and probes into the setting of the weight of the evaluation index and the method of publicizing the evaluation information. According to different levels of colleges and universities, this paper discusses in detail three cases of professional title evaluation based on the point system in the R, S and T colleges and universities, and the maneuverability of this method is mainly discussed. It provides a new train of thought and method for promoting the reform of Professional Title Evaluation in Colleges and universities.

\section{Point System Review Method}

\subsection{Point System}

The point system refers to use point system for the management of teachers, use points to measure teachers' self-worth, reflect and assess the comprehensive performance of teachers, and then link various material treatments, benefits and points, and lean toward high-scoring teachers, in order to motivate teachers' subjective initiative and fully mobilize their enthusiasm. The core content of point system is to use points to record and evaluate the comprehensive performance of teachers and then record it with software. Point system is useful for lifelong. Connect points with the three-dimensional needs, thereby mobilize the inner motivation of teachers, let the excellent teachers not suffer losses and make "loss is a blessing" really become a reality [3].

In the title review, we can assign the content of the review to the system. The factors that involve major principles, such as the party and the government, are necessary and must be achieved. Others, such as teacher's morality, teaching, 
award, patent, dual-master quality, subject, social service, etc., each college can give different weights or points according to the actual situation. After the review is over, the total point of each applicant is summarized. In this way, there are both points for each sub-item and a total of points. Then, according to the situation of the posts of each college, a reasonable line is decided to confirm the final list of the applicants who get the titles and effectively combine review and employment [4].

\subsection{Index Weight}

The Document proposes to pay attention to the basic teaching workload, teaching quality, teaching reform research results, teaching awards and other teaching work performance, to overcome the tendency of only academic qualifications, only qualifications or only papers. At the same time, it is necessary to clarify the important position of the teacher's morality and implement the "one-vote veto" system of teacher's morality. Therefore, how to effectively implement the spirit of the Document combining with the situation of each college is an issue that deserves our in-depth study. We propose that we can explore from the perspective of index weights [5]. On the one hand, the title reform overcomes the "three-dimensional" tendency of only academic qualifications, only qualified qualifications or only papers and adds new elements to the content of the review, such as, the annual teaching workload, teaching evaluation, award, patent, dual-master quality, subject, etc. On the other hand, combining with the actual situation and development direction of each college, the division of weights and points in the content of the review cannot only mean the distribution of values, but also should highlight the difficulties and differences, which cannot only expand the content and scope of the review, but also motivate teachers to develop in multiple directions and take into account the promotion channels of "specialists", effectively using the long-term incentive mechanism for professional titles, in order to achieve a win-win situation for both teachers and colleges.

\subsection{Information Feedback}

After the title review meeting is over, the results need to be announced in a timely manner. By using point system to publicize, the review information can be maximized under the premise of observing the confidentiality principle, and the applicant can be guided to carry out the next review activity. The related public content can be shown in Table 1 .

Table 1 shows that the total points of the four applicants Teacher A, Teacher $\mathrm{B}$, Teacher $\mathrm{C}$ and Teacher $\mathrm{D}$ are 62, 0, 47 and 113, respectively. Two of them are the normal application, one is an exceptive promotion and the other one does not have qualified teacher's morality. If only 2 applicants can be employed by the college, the list can be quickly obtained according to the rank. At the same time, the information in Table 1 reflects the applicants' focuses on various indexes, which also shows the way forward for future applications and improves the openness and fairness of title review. 
Table 1. Example of the results of point system review.

\begin{tabular}{|c|c|c|c|c|c|}
\hline \multirow{2}{*}{ Type } & \multirow{2}{*}{ Review Index } & \multicolumn{4}{|c|}{ Applicant Points } \\
\hline & & Teacher A & Teacher B & Teacher C & Teacher D \\
\hline \multirow{4}{*}{$\begin{array}{c}\text { Prerequisites } \\
\text { (12 Points) }\end{array}$} & Political Standpoint & 3 & 3 & 3 & 3 \\
\hline & Teacher's Morality & 3 & 0 & 3 & 3 \\
\hline & Characters & 3 & 3 & 3 & 3 \\
\hline & Teacher Qualification & 3 & 3 & 3 & 3 \\
\hline \multirow{3}{*}{$\begin{array}{l}\text { Basic Conditions } \\
\quad \text { (24 Points) }\end{array}$} & Dual-master Quality & 8 & 6 & 8 & 0 \\
\hline & $\begin{array}{l}\text { Participating in } \\
\text { College Construction }\end{array}$ & 3 & 5 & 8 & 2 \\
\hline & Daily Teaching & 4 & 6 & 8 & 3 \\
\hline \multirow{7}{*}{$\begin{array}{l}\text { Performance } \\
\text { Conditions } \\
\text { (64 Points) }\end{array}$} & Award & 5 & 2 & 1 & 8 \\
\hline & Patent & 6 & 7 & 1 & 0 \\
\hline & Social Service & 8 & 3 & 5 & 0 \\
\hline & Subject & 8 & 1 & 0 & 0 \\
\hline & Paper & 4 & 2 & 1 & 0 \\
\hline & Teaching Material & 0 & 0 & 0 & 0 \\
\hline & Monograph & 1 & 3 & 0 & 0 \\
\hline \multirow{9}{*}{$\begin{array}{l}\text { Exceptive } \\
\text { Conditions } \\
\text { (88 Points) }\end{array}$} & Works & 3 & 0 & 1 & 0 \\
\hline & Award & 0 & 0 & 0 & 0 \\
\hline & Patent & 0 & 0 & 0 & 0 \\
\hline & Social Service & 0 & 0 & 0 & 0 \\
\hline & Subject & 0 & 0 & 0 & 0 \\
\hline & Paper & 0 & 0 & 0 & 88 \\
\hline & Teaching Material & 0 & 0 & 0 & 0 \\
\hline & Monograph & 0 & 0 & 0 & 0 \\
\hline & Works & 0 & 0 & 0 & 0 \\
\hline \multicolumn{2}{|c|}{ Total Points } & 62 & 0 & 47 & 113 \\
\hline \multicolumn{2}{|c|}{ Rank } & 2 & 4 & 3 & 1 \\
\hline
\end{tabular}

\section{Specific Cases Operation}

\subsection{Connotation Extension and Balanced Points}

Assuming that College $\mathrm{R}$ has a strong comprehensive strength and is currently in a stable period of development, which does not need to emphasize the development in a certain direction, and it needs to maintain a stable growth situation in the next five years. Therefore, the college can use Table 2 as the method of reviewing the title, that is, the equilibrium score with no index weight coefficient.

\subsection{Point-To-Face Emphasis and Different Points}

Assuming that College $S$ is currently in a period of rapid development towards the integration of "production, study and research", and especially encourage 
Table 2. Review standards for associate professors in College R.

\begin{tabular}{|c|c|c|c|}
\hline Type & Review Index & Points & Point Instruction (Examples) \\
\hline \multirow{5}{*}{$\begin{array}{l}\text { Prerequisites } \\
\text { (12 Points) }\end{array}$} & $\begin{array}{c}\text { Political } \\
\text { Standpoint }\end{array}$ & 3 & $\begin{array}{l}\text { Love the motherland and support the Chinese } \\
\text { Communist Party }\end{array}$ \\
\hline & $\begin{array}{l}\text { Teacher's } \\
\text { Morality }\end{array}$ & 3 & Do well to be a teacher with good morality \\
\hline & Characters & 3 & Have excellent style with no crimes \\
\hline & $\begin{array}{c}\text { Teacher } \\
\text { Qualification }\end{array}$ & 3 & $\begin{array}{l}\text { Obtain the qualification certificate of college teach- } \\
\text { ers }\end{array}$ \\
\hline & $\begin{array}{l}\text { Dual-master } \\
\text { Quality }\end{array}$ & 8 & $\begin{array}{l}\text { Combine teaching and practice with good profes- } \\
\text { sional quality }\end{array}$ \\
\hline \multirow[t]{5}{*}{$\begin{array}{l}\text { Basic Conditions } \\
\quad \text { (24 Points) }\end{array}$} & $\begin{array}{l}\text { Participating in } \\
\text { College } \\
\text { Construction }\end{array}$ & 8 & $\begin{array}{l}\text { Participate in college construction and related public } \\
\text { welfare activities }\end{array}$ \\
\hline & Daily Teaching & 8 & $\begin{array}{l}\text { Achieve the required amount of teaching working } \\
\text { load with good teaching evaluation and no teaching } \\
\text { accidents in the past three years }\end{array}$ \\
\hline & Award & 8 & $\begin{array}{l}\text { National awards is the highest, according to the turn } \\
\text { of provinces, cities and colleges }\end{array}$ \\
\hline & Patent & 8 & $\begin{array}{l}\text { The invention patent is the highest and the utility } \\
\text { model and appearance patent are lowest in turn }\end{array}$ \\
\hline & Social Service & 8 & $\begin{array}{l}\text { From subject to the college funding level, horizon- } \\
\text { tally from high and low }\end{array}$ \\
\hline \multirow{8}{*}{$\begin{array}{l}\text { Performance } \\
\text { Conditions } \\
\text { (64 Points) }\end{array}$} & Subject & 8 & $\begin{array}{l}\text { The higher the project level is, the higher the point } \\
\text { will be }\end{array}$ \\
\hline & Paper & 8 & $\begin{array}{l}\text { Papers are given points according to grade, rank and } \\
\text { impact factor }\end{array}$ \\
\hline & Teaching Material & 8 & $\begin{array}{l}\text { Teaching material is given points according to grade } \\
\text { and rank }\end{array}$ \\
\hline & Monograph & 8 & $\begin{array}{l}\text { Monograph is given points according to the number } \\
\text { of words }\end{array}$ \\
\hline & Works & 8 & Works are given points according to influence \\
\hline & Award & 88 & $\begin{array}{l}\text { Obtain national third prize and above, and ranked } \\
\text { the top two }\end{array}$ \\
\hline & Patent & 88 & $\begin{array}{l}\text { Obtain no less than } 2 \text { invention patents as the first } \\
\text { inventor }\end{array}$ \\
\hline & Social Service & 88 & $\begin{array}{l}\text { Obtain significant horizontal project funding of no } \\
\text { less than } 2 \text { million }\end{array}$ \\
\hline \multirow{5}{*}{$\begin{array}{l}\text { Exceptive } \\
\text { Conditions } \\
\text { (88 Points) }\end{array}$} & Subject & 88 & Host national research projects \\
\hline & Paper & 88 & $\begin{array}{l}\text { The number of papers included in core journals such } \\
\text { as SCI and EI is no less than } 5 \text { as the first author }\end{array}$ \\
\hline & Teaching Material & 88 & $\begin{array}{l}\text { Edit more than } 2 \text { national planning teaching } \\
\text { materials as chief editor }\end{array}$ \\
\hline & Monograph & 88 & $\begin{array}{l}\text { Published by a national publishing house, the } \\
\text { number of words is not less than } 10\end{array}$ \\
\hline & Works & 88 & $\begin{array}{l}\text { Published by a national publishing house, the } \\
\text { number of drawings is not less than } 30\end{array}$ \\
\hline
\end{tabular}

and support teachers to participate in various social service projects and improve professional capabilities. In the next five years, College $S$ will focus on supporting patent and social service. Therefore, College $S$ can refer to the method of 
Table 3 in reviewing title, that is, the different points. Patent and social service have the largest weighting factor of 0.26 .

\subsection{Weight Distribution and Scientific Evaluation}

Assuming that College $\mathrm{T}$ is currently large in scale and it is difficult to determine the content of title review. At this point, it can be solved by comprehensively using the index evaluation method. At present, the most commonly used index evaluation methods are Analytic Hierarchy Process (AHP), Precedence Chart (PC), Percentile Ratio Method, Rank-sum ratio (RSR), Technique for Order Preference by Similarity to an Ideal Solution (TOPSIS), Fuzzy Judgment Method, etc. [6]. This paper takes AHP and PC as examples to illustrate the importance selection of title review for reference.

1) Analytic Hierarchy Process (AHP)

Table 3. Review standards for associate professors in College S.

\begin{tabular}{|c|c|c|c|c|}
\hline Type & Review Index & Weights & Points & Point Instruction (Examples) \\
\hline \multirow{4}{*}{$\begin{array}{l}\text { Prerequisites } \\
\text { (12 Points) }\end{array}$} & Political Standpoint & - & 3 & \multirow{23}{*}{ The same as Table 2} \\
\hline & Teacher's Morality & - & 3 & \\
\hline & Characters & - & 3 & \\
\hline & Teacher Qualification & - & 3 & \\
\hline \multirow{3}{*}{$\begin{array}{l}\text { Basic Conditions } \\
\quad \text { (24 Points) }\end{array}$} & Dual-master Quality & - & 8 & \\
\hline & $\begin{array}{l}\text { Participating in College } \\
\text { Construction }\end{array}$ & - & 8 & \\
\hline & Daily Teaching & - & 8 & \\
\hline \multirow{8}{*}{$\begin{array}{l}\text { Performance } \\
\text { Conditions } \\
\text { (64 Points) }\end{array}$} & Award & 0.08 & 8 & \\
\hline & Patent & 0.26 & 8 & \\
\hline & Social Service & 0.26 & 8 & \\
\hline & Subject & 0.08 & 8 & \\
\hline & Paper & 0.08 & 8 & \\
\hline & Teaching Material & 0.08 & 8 & \\
\hline & Monograph & 0.08 & 8 & \\
\hline & Works & 0.08 & 8 & \\
\hline \multirow{8}{*}{$\begin{array}{l}\text { Exceptive } \\
\text { Conditions } \\
\text { (88 Points) }\end{array}$} & Award & - & 88 & \\
\hline & Patent & - & 88 & \\
\hline & Social Service & - & 88 & \\
\hline & Subject & - & 88 & \\
\hline & Paper & - & 88 & \\
\hline & Teaching Material & - & 88 & \\
\hline & Monograph & - & 88 & \\
\hline & Works & - & 88 & \\
\hline
\end{tabular}


Analytic Hierarchy Process was proposed by American operations researcher T.L. Saaty in the 1970s. It is a combination of qualitative and quantitative methods [7]. The expert's subjective language judgment results are constructed into a digital matrix according to a certain numerical scale, thereby analyzing whether the matrix has satisfactory consistency. If satisfied, the expert opinion can be applied to the actual; if not, the expert opinion needs to be revised until a satisfactory consistency requirement is reached. The disadvantage is that it is limited by the number of indexes, generally no more than nine. At the same time, because the meaning of the scale value is not easy to understand, it is not suitable for a wide range of investigations. AHP scale is shown in Table 4.

College $T$ conducted a questionnaire survey of 10 experts on campus. According to the opinions of them, the survey results are shown in Table 5.

From Table 5, the 8th order judgment matrix $A$ can be obtained (The values of the rows and columns in Table 5 form the rows and columns of the matrix, which should be aij element in matrix $A$ respectively). Since no high precision is required in this paper, the approximation method can be used to calculate the approximation of the eigenvalues. The steps are as follows [8]:

a) First normalize matrix A by column: $b_{i j}=\frac{a_{i j}}{\sum a_{i j}},(i, j=1,2,3, \cdots, 8)$;

b) Normalize the matrix by row: $c_{i}=\sum b_{i j},(i, j=1,2,3, \cdots, 8)$;

c) Normalize $c_{i}$ and get the eigenvector: $W=\left(w_{1}, w_{2}, \cdots, w_{8}\right)^{\mathrm{T}}, w_{i}=\frac{c_{i}}{\sum c_{i}}, W$ is the approximate value of eigenvector $A$;

d) Find the maximum eigenvalue corresponding to the eigenvalue vector $W$ : $\lambda_{\max }=\frac{1}{n} \sum_{i}\left(\frac{(A W)_{i}}{w_{i}}\right),(n=8, i=1,2,3, \cdots, 8)$.

Through the calculation of the above steps, the maximum eigenvalue can be obtained $\lambda_{\max }=8.0133884$. According to the principle of hierarchical method, the consistency of the theoretical maximum eigenvalue $\lambda_{\max }$ of $\mathrm{A}$ and the difference of $\mathrm{n}$ is used to test the consistency, and the consistency index is obtained $C I=\frac{\lambda_{\max }-n}{n-1}=\frac{8.0133884-8}{8-1}=0.001913$, which is close to 0 with satisfactory

Table 4. AHP proportion scale.

\begin{tabular}{cc}
\hline $\mathrm{A}_{\mathrm{ij}}$ (Factor i: Factor $\left.\mathrm{j}\right)$ & Meanings \\
\hline 1 & Equally important \\
3 & Slightly important \\
5 & Stronger important \\
7 & Strongly important \\
9 & Extremely important \\
$2,4,6,8$ & Intermediate value of two adjacent judgments \\
\hline
\end{tabular}


Table 5. AHP index method evaluation result.

\begin{tabular}{|c|c|c|c|c|c|c|c|c|}
\hline $\begin{array}{l}\text { Review } \\
\text { Index }\end{array}$ & Award & Patent & $\begin{array}{l}\text { Social } \\
\text { Service }\end{array}$ & Subject & Paper & $\begin{array}{l}\text { Teaching } \\
\text { Material }\end{array}$ & Monograph & Works \\
\hline Award & 1 & $1 / 9$ & $1 / 9$ & $1 / 8$ & $1 / 8$ & $1 / 3$ & $1 / 5$ & $1 / 2$ \\
\hline Patent & 9 & 1 & 1 & 4 & 4 & 5 & 6 & 3 \\
\hline $\begin{array}{l}\text { Social } \\
\text { Service }\end{array}$ & 9 & 1 & 1 & 7 & 1 & 5 & 5 & 6 \\
\hline Subject & 8 & $1 / 4$ & $1 / 7$ & 1 & 1 & 4 & $1 / 3$ & 1 \\
\hline Paper & 8 & $1 / 4$ & 1 & 1 & 1 & 3 & 2 & 1 \\
\hline $\begin{array}{l}\text { Teaching } \\
\text { Material }\end{array}$ & 3 & $1 / 5$ & $1 / 5$ & $1 / 4$ & $1 / 3$ & 1 & 1 & 1 \\
\hline Monograph & 5 & $1 / 6$ & $1 / 5$ & 3 & $1 / 2$ & 1 & 1 & $1 / 3$ \\
\hline Works & 2 & $1 / 3$ & $1 / 6$ & 1 & 1 & 1 & 3 & 1 \\
\hline
\end{tabular}

consistency. Considering that the deviation of consistency may be caused by random reasons, when checking whether the judgment matrix has satisfactory consistency, it is also necessary to compare CI with the random consistency index RI to obtain the test coefficient CR. By querying the average random consistency index, RI value of the 8 th order matrix is 1.41 , and the test coefficient $C R=\frac{C I}{R I}=\frac{0.001913}{1.41}=0.001356<0.1$ can be obtained. According to AHP, the judgment matrix A passes the consistency test.

In summary, the evaluations of 10 experts are consistent and the results are credible. After obtaining the relative importance between the elements at the same level, it is possible to calculate the comprehensive importance of the elements at all levels from the top to the bottom, that is, the weight of each evaluation index. Through calculation, the index weight of each evaluation index is shown in Table 6.

According to Table 6, it can be seen that the weights of patent, social service and paper are ranked at top 3 , which means that the requirements of the three indexes are higher.

2) Precedence Chart (PC)

Precedence Chart was proposed by an American scholar P.E. Moody in 1983. It also uses the matrix method to analyze the importance of each factor and provide a basis for management decision-making. The simple operation method is to use " 1 " and "0" to reflect the degree of importance. "1" means that one index is more important than the other, and " 0 " means that one index is less important than the other. Finally, the summary quantity is sorted. The larger the number is, the higher the importance is, and the smaller the number is, the lower the importance is. The advantages of this method are that the meaning is simple and clear and it can be used for large-scale data survey. The disadvantages are that it is subjective and it is not distinguishable [9] [10].

In the early stage, 200 questionnaires were distributed and collected for various teachers of College T. According to the opinions of them, the survey results are shown in Table 7. 
Table 6. The weights of the indexes in AHP index evaluation.

\begin{tabular}{cc}
\hline Review Index & Index Weight \\
\hline Award & 0.021 \\
Patent & 0.296 \\
Social Service & 0.284 \\
Subject & 0.080 \\
Paper & 0.123 \\
Teaching Material & 0.051 \\
Monograph & 0.066 \\
Works & 0.079 \\
\hline
\end{tabular}

Table 7. PC index review results.

\begin{tabular}{cccccccccccc}
\hline Review Index & Award & Patent & $\begin{array}{c}\text { Social } \\
\text { Service }\end{array}$ & Subject & Paper & $\begin{array}{c}\text { Teaching } \\
\text { Material }\end{array}$ & Monograph & Works & Points & $\begin{array}{c}\text { Index } \\
\text { Weight }\end{array}$ Rank \\
\hline Award & 0 & 35 & 20 & 65 & 34 & 120 & 100 & 110 & 484 & 0.0864 & 7 \\
Patent & 165 & 0 & 90 & 120 & 10 & 150 & 139 & 160 & 834 & 0.1489 & 2 \\
Social Service & 180 & 110 & 0 & 170 & 12 & 134 & 32 & 170 & 808 & 0.1443 & 3 \\
Subject & 135 & 80 & 30 & 0 & 70 & 158 & 102 & 180 & 755 & 0.1348 & 5 \\
Paper & 166 & 190 & 188 & 130 & 0 & 128 & 101 & 150 & 1053 & 0.1880 & 1 \\
Teaching Material & 80 & 50 & 66 & 42 & 72 & 0 & 97 & 115 & 522 & 0.0932 & 6 \\
Monograph & 100 & 61 & 168 & 98 & 99 & 103 & 0 & 167 & 796 & 0.1421 & 4 \\
Works & 90 & 40 & 30 & 20 & 50 & 85 & 33 & 0 & 348 & 0.0622 & 8 \\
\hline
\end{tabular}

In Table 7, taking the index award as an example, the data indicates that there are $35,20,65,34,120,100$, and 110 applicants think that the award is more important than patent, social service, subject, paper, teaching material, monograph and works. The award index is 484 points. Index weight is calculated by dividing the point by the sum of the points of all indexes, that is, $484 / 5600=0.0864$. Other indexes are calculated in the same way. According to the index weight value, it can be known that the top three indexes are paper, patent and social service.

\section{Advantage Analysis of Point System Review Method}

The advantages of point system review method mainly include the following three aspects:

1) Effective feedback on review information, promoting teacher development

The method in Table 1 can effectively feedback the information of professional title evaluation, especially for the applicants who failed to get the titles, it can effectively improve the guidance and pertinence of title review and greatly improve the openness and fairness of title review. It can promote the development of teachers to some extent.

2) The point system highlights the difference between high and low, and the 
problem of the separation of review and employment is solved.

The use of point system can distinguish the differences in the performance of teachers in all aspects, which effectively overcomes the vagueness of the voting system and the difficulty of the same vote. Being similar to the college entrance examination scores which is from high to low, in point system, according to how many professors and associate professors are required in each college, the corresponding score line can be decided and the problem of difficult in review and employment is naturally solved.

3) Index weights show key points and lead the later strategic development of colleges

In the process of title review, the point system is introduced. Different index weights are set according to the situation of each college, which can lead the development direction, highlight the key points and characteristics of the development and enhance the centripetal force and cohesiveness of all personnel of the college for a period of time.

\section{Conclusion}

More than a year after the publication of the "IODRSAOSHEGD" document, many colleges and universities in Guangdong Province are undergoing professional title review reform. South China Business College of Guangdong University of Foreign Studies adopted the method of professional title evaluation based on the point system proposed in this paper, and achieved good results. However, the index setting and index weight of title evaluation need further study, which is the key of this professional title evaluation model. Colleges and universities can set different indexes and weights according to their own development needs and strategic orientation, enhance the incentive effect of titles and realize the two-way interaction and win-win between colleges and teachers.

\section{Conflicts of Interest}

The authors declare no conflicts of interest regarding the publication of this paper.

\section{References}

[1] Xie, F.H. (2000) Scientific Measurement and Expert Review-On the Reform of University Teachers' Title Review. Higher Education Research, 3, 69-73.

[2] Yu, X.L. (2011) Research on the Construction of Professional Title Review System Based on Fairness. China Administration, 11, 77-80.

[3] Li, R. (2014) The Use of Point System Management in Innovative Social Management. People's Political Consultative Conference, 2014-03-01. (03: Special Edition) http://dzb.rmzxb.com/index.aspx?date=2014-03-01\&verOrder=03\&banzi=2\&paper Type $=$ rmzxb

[4] Yu, Q.D. and Wang, W.M. (2013) Examining and Rethinking: The Application of Evaluation Standards for Professional Titles in Higher Vocational Education in China. Teacher Education Research, 1, 17-21.

[5] Hong, X.Z. and Wang, Y.Z. (2016) Evaluation Index System of Corporation's Inno- 
vation Capacity and Application Study. Technology and Investment, 7, 143-151. https://doi.org/10.4236/ti.2016.74016

[6] Wang, T. (2016) Members' Supplementary Decision-Making during the Operation of "Single-Core" Virtual R \& D Team. China Human Resources Development, 10, 35-40.

[7] Raza, M.S., Fayaz, M., Ijaz, M.H., Hussain, D. and Rubab, S. (2017) Money Laundering Risk Evaluation of Financial Institution with AHP Model. Journal of Financial Risk Management, 6,119-125. https://doi.org/10.4236/jfrm.2017.62010

[8] Tong, J. (2018) Evaluation of College Students' Employment Quality Based on Analytic Hierarchy Process. Science and Technology Management Research, 2, 160-164.

[9] Cao, T.T., Lu, G.Z., Wang, X.H., Liu, S.J. and Zheng, T.Y. (2016) Construction of ICU Hospital Infection Risk Review Index System Based on Delphi and Excellent Sequence Diagram Method. Journal of Nursing Science, 3, 44-47.

[10] Chen, L.J., Song, Y., Wang, H., Xiao, G.Y. and Hu, S.W. (2017) Optimization of Deep Foundation Pit Support Scheme Based on Delphi Method and Superior Sequence Diagram Method. Journal of Guilin University of Technology, 10, 514-518. 